\title{
Atheism Plus What? Social Justice and Lifestyle Politics Among Edmon-
} TON ATHEISTS

\author{
JONATHAN SimMONS
}

Abstract. This article addresses Edmonton secularists' responses to the emergence of a social justice faction known as Atheism Plus (A+) within the broader secularist movement. I show that some atheist activists express a libertarian rationalism consistent with Enlightenment values to maintain a lifestyle free from collectivist ideologies that promote social justice. The data for this article comes from interviews and participant observation, focusing on three atheist organizations in Edmonton, Alberta, Canada. I draw from literature focused on everyday lifestyle choices as a form of protest to argue that for some atheist activists, their individual intellectual development takes priority over building a strong collective identity. Given that some scholars claim that atheism perpetuates gender inequality (Amarasingam and Brewster 2016; Miller 2013; Schnabel 2015), this work additionally contributes to our understanding of how atheists conceptualize their activism as sub- and micro-political activities free from community constraints.

Keywords: Sociology of religion; Social movement studies; New atheism; Lifestyle; Identity; Religion; Schisms

Résumé. Cet article porte sur les réactions des athées d'Edmonton face à l'émergence d'une faction vouée à la promotion de la justice sociale connue sous le nom d'Athéisme Plus $(\mathrm{A}+)$ au sein du mouvement laïc plus large. Je montre que certains militants athées expriment un rationalisme libertaire conforme aux valeurs des Lumières pour maintenir un style de vie dépourvu d'idéologies collectivistes favorisant la justice sociale. Les données utilisées dans cet article proviennent d'entrevues et d'une observation participante portant sur trois organisations athées à Edmonton, Alberta, Canada. Je me fonde sur la littérature concernant les choix de la vie quotidienne comme une forme de protestation afin de souligner que, pour certains activistes athées, le développement intellectuel individuel a la priorité sur la construction d'une identité collective forte. Étant donné que certains chercheurs affirment que l'athéisme perpétue l'inégalité de genre (Amarasingam et Brewster 2016, Miller 2013 et Schnabel 2015), cette recherche contribue également à faire mieux comprendre comment les athées 
conceptualisent leur activisme en tant qu'activités sous- et micro-politiques libérées des contraintes communautaires.

Mots clés: Sociologie de la religion; Études de mouvements sociaux; Nouvel athéisme Mode de vie; Identité; Religion; Schismes

The prime target of the social justice movement is people who are almost exactly like themselves. Social justice people weren't targeting the Westboro Baptists. They weren't targeting Boko Haram or any of their natural enemies. They weren't really targeting Republicans that much. They were mostly targeting 'enlightened liberals' who just had a slightly different opinion than them (Igor, Age 34)

\section{INTRODUCTION}

1 Ithough empirical research on atheism in Canada is limited, irreligion is common in many provinces, with many Canadians ending up as unaffiliated "nones." Statistics Canada data reveals that 23.9\% of Canadians self-identify as nones when asked to place their religion (Statistics Canada 2013). The nones, however, are not a homogenous group, with a presumably smaller percentage identifying as atheists and agnostics (Wilkins-Laflamme 2015). Nevertheless, atheism in Canada appears to be growing, which is consistent with trends in other Western developed countries (Cipriani and Garelli 2016; Tomlins 2015). The recent increase in scholarly focus on atheism suggests that the social context of organized non-belief has (sociological) merit, particularly regarding the implications of the atheist movements' potential social, political, and cultural salience.

In this article, I am primarily interested in examining the politics of secularist activism in Canada, particularly the current view that atheists fall somewhere left-of-centre on social issues (Cimino and Smith 2014). My contribution is to examine Edmonton atheist activists' responses to an intra-movement and intra-community tension around whether secularits should strive to achieve equity and fight for social and economic relations, focusing on the emergence of a faction known as Atheism Plus.

The term Atheism Plus designates "spaces, persons, and groups dedicated to promoting social justice and countering misogyny, racism, homo/bi/transphobia, ableism and other such bigotry inside and outside of the atheist community" (as cited in Beaman and Tomlins 2014: 65). To set the stage for Atheism Plus's emergence, my starting point for this article is what came to be known as "elevatorgate," after secularist blogger Rebecca Watson uploaded a YouTube video called "About 
Mythbusters, Robot Eyes, Feminism, and Jokes." In the video, Watson recounts her experiences at a World Atheist Convention in Dublin, Ireland (Watson 2011). She describes her discomfort with allegedly being propositioned in a hotel elevator (hence the term elevatorgate) following her talk about sexism within the atheist community.

Since Watson's video, the atheist community has suffered from infighting over the direction of atheist activism, that is, whether atheism should be social justice oriented. Informed by the mainly online controversy, this article examines Canadian atheist activists' offline responses to so-called "social justice warriors" (SJWs), like Watson, who want a more robust atheist movement that reflects progressive communitarian values (Anne 2012; Laughlin 2017; Nixon 2014). I add nuance to the idea that atheists are politically left-of-centre, arguing that some atheist activists express a libertarian rationalism, privileging an individual identity over collective identity, largely as an attempt to promote a lifestyle free from ideologies that appear incompatible with Enlightenment values.

Although Atheism Plus seems to be declining as a faction, many of its supporters continue to argue that New Atheism has a "sexism problem" and that it is an "old boys' club" (McCreight 2011; Smurthwaite 2016). If true, this characterization of atheist activists runs counter to the view that secularists are left-wing, especially when it comes to social issues. Given that most research points to atheists as being liberal and progressive (Cimino and Smith 2014), my findings show that some atheist activists manifest complex political identities that may go beyond conventional political sympathies. The atheist activists featured in this study shared a dim view of feminism generally, and Atheism Plus specifically, supporting their aversion to social justice activism by emphasizing an ideology of libertarian individualism.

In what follows, I assess atheism's libertarian character, especially when it comes to affirming individualism over communitarian values of diversity, justice, and solidarity (Bennett 2012: 22; LeDrew 2015b). This focus on lifestyle departs from previous approaches to atheist activism, deemphasizing the importance of atheist collective identity, and instead highlighting personal identity as the primary site of social change (Lorenzen 2012; Portwood-Stacer 2012). Stephen LeDrew (2013) argues that atheism may not follow "traditional structure-centered approaches" to collective action. Given that secularist activism is "identity-based," I use Haenfler et al.'s (2012: 2) work on lifestyle movements to argue that Canadian atheist activists promote a "lifestyle, or way of life, as their primary means to foster social change." Through this framework, I highlight the libertarian character of some forms of atheist activism. I 
show how atheist activists see their avoidance of contemporary progressive identity politics as a fulfillment of their personal politics, which often connects scientism to radical individualism, consequently limiting secularists' ability to advance human equality (LeDrew 2015b; Laughlin 2017).

\section{BACKGROUND}

Over the past decade, sociologists have contributed to a sound understanding of New Atheism and the growth of atheist social movement organizations (Langston et al. 2015; Zuckerman et al. 2016). Much of this work focuses on collective identity construction and collective performances or practices (see Cimino and Smith 2014; Kettell 2014; LeDrew 2015a; Smith 2013; Smith and Cimino 2012). Some exceptions include recent attempts to investigate the politics of atheism, often highlighting the individualistic (and libertarian) character of atheist activism (Kettell 2013; Laughlin 2017; LeDrew 2013). Of more relevance to this article, some scholars have attempted to highlight the heterogeneity of secularist identities (Amarasingam and Brewster 2016; LeDrew 2013; Tomlins 2016). Nevertheless, much of this previous work retains a bias towards the role that organizations play in atheist collective identity construction. In this article, I examine how atheist activists individually negotiate their political identities and lifestyles within the context of (broader) social/ sociopolitical categories, such as sex and gender.

In addition to being limited to collective identity approaches to atheist movements, most atheism scholarship focuses on the American context. Comparatively, the study of atheist activism in Canada is understudied. It is far more common to find a broader discussion of the religiously unaffiliated or religious nones in Canada than atheist activism (Voas 2015; Wilkins-Laflamme 2015). Some exceptions include an examination of a university atheist community and the heterogeneity in trajectories to atheism and atheist activism in Canada (LeDrew 2013; Tomlins 2015).

Although there may be significant differences between American and Canadian secularists, I draw mostly from the US literature, in part because of the lack of a robust equivalent in Canada and partly because my participants often commented on the US context. As one participant put it, the Canadian atheist movement follows US trends:

I do think that we try to imitate the Americans. Like, [our president] is tight with David Silverman [president of American Atheists]. He basically showed her how to run everything, how to bring in members, that sort of thing (Sam, Age 31). 
Like Sam, my other participants primarily read US-based atheist authors, websites, blogs, podcasts, and social media to keep themselves apprised of what was happening in the movement.

Although it is beyond the scope of this study to compare Canadian and American atheists, my broader findings are consistent with other scholars' findings: Canadian secularists make use of US atheist discourses and express views comparable to American libertarian rationalism (LeDrew, 2015). Additionally, my participants embodied what Steven Tomlins (2015: 135) refers to as "Canadianized Atheism." This term refers to Canadian atheists' preference for politeness and likability, merging with "the desire to engage in discussions with like-minded individuals on topics pertaining to religion that are often controversial." Many of my participants were personally antagonistic towards religion, but they felt that the need for confrontational activism was less important in Canada than in the US, which they described as a more religious county, both regarding private devotion and public religion.

\section{Lifestyle Movements}

With the "cultural turn" in social movement studies, scholars have increasingly emphasized the importance of collective identity and action as central to understanding newer social movements (Haenfler et al. 2012; Marx and McAdam 1994). Despite this shift, some recent studies have claimed that individualized prosocial choices among activists are important forms of political behavior (Dobernig and Stagl 2015; Yates 2015).

Scholars of lifestyle movements argue that lifestyle choices as tactics for social change hinge on personal identity work and a commitment to living consistently, according to various principles (Micheletti and Stolle 2015). These principles may be moral repertoires or combinations of principles tied to the tenets of a particular movement or a more personalized ethical compass (Kahl 2012). Lifestyle movements consequently blur the line between public and private and individual identity and collective action (Bennett 2012; Cherry 2015; Lorenzen 2012; Willis and Schor 2012). Informed by these lifestyle-focused approaches, I draw attention to how secularists pride themselves on their individualism, see everyday life as politically significant, and use this emphasis on personal politics to shield themselves against ideology-based politics.

Personalized politics represents not only my participants' preferred approach to activism but also a defensive bulwark against the excesses of ideology (which some atheists perceive to be inherent to religion). De- 
spite this emphasis on individualism, as others have noted, the conceptual category "atheism" includes a significant set of assumptions closely resembling what LeDrew (2015b: 34) refers to as scientific atheism (as opposed to humanistic atheism) and the notion that "society advances in lockstep with science." Consistent with these findings, my participants shared an attachment to an Enlightenment ideology of reason, science, and autonomy. The conflict between my participants' embrace of an individualistic ideology and their ambivalence towards ideologies that seek to change structural inequalities is a theme in my interview data. To make sense of this apparent contradiction I examine my participants' desire for societal change through individualized action, that is, daily choices to improve the world through reason and science.

\section{Methods}

This article draws from a broader two-year project focused on Canadian secularists in the province of Alberta. What follows is primarily drawn from my fieldwork and interviews in the city of Edmonton. Using a qualitative case study research design, I investigated self-described atheist activists using multiple methods of data collection (Algozzine and Hancock 2015; Snow and Trom 2002). A case study is a research strategy based on the in-depth empirical investigation of a case. Along with focusing on a particular context in real time, doing case study research leads to an embedded understanding of a phenomenon.

Critics of the case study point out that the one cannot generalize from a single case and that the case study approach lacks rigour. Responses to this criticism are varied and well-established in the literature (Flyvbjerg 2006). Despite the perceived or actual limitations of the case study method, the approach allowed me to gather holistic information about my participants' lived experiences and consider "the context and other complex conditions related to the case being studied" (Yin 2011: 4). I used participant observation and semi-structured interviews as my primary data collection methods. I also analyzed organizational documents and social media content related to atheists' community building and activism. I fully transcribed data from all participants, which I then analyzed for recurring themes through open coding in NVivo [10]. I drew from analytical devices from the relevant literature on lifestyle movements to guide categorizing open codes into a more structured coding scheme.

My research participants included over fifty self-described atheists from multiple atheist organizations with a combined offline and online membership of over 1500 people. I conducted thirty-five semi-structured 
interviews with my core participants, focusing on those atheists who continued to live in the Edmonton-area and were active members of one or more local organizations. I recruited members through a combination of convenience and snowball sampling. My sample included sixteen women and nineteen men, ranging from ages 20 to 63 . The interviews lasted between 60 and 90 minutes. We discussed a range of issues including stigma against atheists, secularism, bridge-building with religious groups, the meaning of various identity markers (i.e., skeptic, secular humanist, freethinker, etc.), and political issues within local organizations and the broader movement.

I drew potential participants from three organizations: The Society of Edmonton Atheists (SEA), The University of Alberta Atheists and Agnostics (UAAA), and the Greater Edmonton Skeptics Society (GESS). I selected the above organizations based on the frequency of their meetings and events, their social media presence, and their reasonable proximity to one another. I met with a local secular humanist group, but meetings were infrequent and attended by a comparatively small number of people. Also, there was little overlap between the humanist group and the other organizations featured in my study, largely because the secular humanists I encountered had little interest in building an atheist community or engaging in organized activism. I commenced my study upon approval of the University of Alberta Research Ethics Office (REO) in 2014. After approval, I contacted each organization after either locating an organization's email or from their social media presence (usually Facebook). The presidents of the three organizations quickly granted me access.

Of my thirty-five interviewees, roughly half primarily associated themselves with SEA, but most were involved with UAAA and GESS as well. Most of my participants had some level of post-secondary education, or they were in the process of pursuing higher education. Except for five of my participants, all of the members of SEA and GESS held a bachelor degree or greater. Members of the UAAA, for obvious reasons, were currently enrolled in undergraduate degrees. Twenty-nine of thirtyfive of my participants identified with a Christian cultural background. Two participants had grown up in explicitly atheist or agnostic households. Two participants had Muslim backgrounds, one had Neopaganism affiliations, and another identified as culturally Jewish. Politically, most of my interviews identified as left, liberal, or libertarian. 


\section{Libertarianism or Social Justice?}

Describing the fallout from Watson's YouTube video, Cimino and Smith (2014: 97) argue that the "blogosphere went ablaze with a blog war between those siding with Watson and those critical of her, including other female atheists." Spurred on by the support of some members of the atheist community and personal stories of sexism and misogyny at atheist events, some self-described feminist atheists called for a "third wave" of atheism, its purpose being to challenge status quo atheism and guide the movement in a more social justice orientated direction (Myers 2011).

In keeping with Atheism Plus's critiques, some scholars have pointed out that prominent figures in New Atheism see multiculturalism and gender equality as a threat to the hegemonic white, male atheist community (Amarasingam and Brewster 2016). My participants presented a different view that often highlighted their individualism over collective struggles against systems of power and oppression, e.g., racism, classism, Ageism, heterosexism:

I'm not into identity politics. I'm not jumping on any bandwagons. I don't believe in institutionalized sexism or any of that stuff [...] or at least not how most people talk about it. Even if I did, we can't be all things to all people, and it's not my job to hold the flag for all these other causes. I guess I'm pretty libertarian when it comes to that sort of thing. You do you, and I'll do me (Maisie, Age 26).

Like Maisie, most of my participants saw the emergence of Atheism Plus as a challenge to the individualism of atheist activism. In particular, many of my interviewees felt that no one person or organization should be able to speak as a representative of others within the movement. For example, Serena (Age 25) expressed her dissatisfaction with the "idea of a feminist group steering the movement away from its roots." Similarly, Tracy (Age 21) said, "I remember when we used to get together and learn about logical fallacies, cognitive biases. All that stuff. I don't want them [atheist organizations] becoming political parties. If that happens, I'm out."

My participants' concerns about maintaining the individualism of atheist activism are similar to the attitudes one finds in other lifestyle movement members, e.g., individualistic vegans who have little interest in unifying and are wary of organized vegans (Cherry 2015; Larsson et al. 2003). Although my participants did not disassociate themselves from other atheists, they did not conform to traditional social movement behavior, e.g., organized, goal-oriented, collective action (Marx and McAdam 1994). My participants' went further than just criticizing Athe- 
ism Plus, also emphasizing the personalization of atheist activism. For example, AJ (Age 29) discussed the "herding cats" metaphor as an ideal model for atheist activism:

Atheism's strength is that it doesn't have an ideology. That's why it's so hard to bring us together. We've all heard that organizing atheists are like herding cats. Well, that's true! And it's a good thing because it means we can be ourselves and we're not beholden to any particular hierarchy, manifesto, or whatever.

AJ's reticence to build a general movement suggests that in some movements individuals' narratives can eclipse collective identity frames, and this is consistent with other lifestyle movements that emphasize commitment to a strong personal identity (Haenfler 2004).

Sometimes, my participants' emphasis on atheism as an individualistic project manifested in what LeDrew (2015b: 203) regards as a "libertarian defense of individualism and denial of structural barriers to social mobility." For example, Maisie (Age 26), who I mentioned earlier, denied institutionalized sexism. Similarly, Max (Age 22) argued that Atheism Plus ran counter to both his view of atheism and how he wanted to approach activism:

First of all, name one right that men have that women don't have? That's my first question to Atheism Plus. Second, most of our executives are women [...] I don't want a group of bloggers telling me that I need to believe $\mathrm{X}$ or $\mathrm{Y}$ in order to be a good person. Atheism should be about atheism at the end of the day. It should be about science and reason, not left-wing politics.

Although most of my participants identified as politically left-leaning, expressing their support for the New Democratic Party (NDP), which is a social democratic party, they nevertheless expressed their preferences for individualism when it came to their atheist activism.

According to LeDrew (2015), libertarians are the most important group of right-leaning atheists, their primary goal being the protection of individual freedoms. Although only four of my participants identified as politically libertarian, most of my participants saw the atheist lifestyle as consisting of Enlightenment values like individualism, rationality, and the use of science.

A self-described libertarian, Serena (Age 25) described her issue with Atheism Plus as having less to do with what it stood for than who was controlling the narrative regarding social justice: 
I don't like other women claiming that they speak for me or that their issues are women's issues. I'm an individual. I happen to have female parts, but that's about the only thing I have in common with 'women.' Also, there's no one way to be a feminist.

The notion that someone was "speaking for them" particularly concerned many of my interviewees, revealing a tension in their approaches to activism, given their ongoing participation in secularist organizations. After bringing this issue to the attention of some my interviewees, many acknowledged a constant tension between their desire for social change and their caution regarding organized activism:

It would be nice if we had more of an impact, but I dare you to find another 'movement' [...] that has as many different types of people in it. I don't think you get that with a manifesto and marches. You get conformity. There's something really anarchic about atheism, and that's why I love it (Connor, Age 27)

Unlike traditional social movement organizations, lifestyle movement organizations (LMOs) create an extra layer of meaning for members, but they do so in the service of individual action (Haenfler et al. 2012: 8). Consequently, secularist organizations may have a relatively weak collective identity compared to more goal-directed, hierarchical organizations. According to many of my participants, secularist organizations should limit themselves to supporting members' daily choices, allowing secularists to exploit tactical repertoires according to their personal preferences.

My findings show that some secularists choose a lifestyle consistent with scientific atheism and the view that religion is the antithesis of science (LeDrew 2015b: 14), contrasting sharply with humanistic atheism and its emphasis on social justice. For example, one of my politically libertarian respondents valourized the autonomous creative individual:

I'd rather not be dependent on organizations. I've seen too many movements fail because crappy organizations. I think one individual making a change in aggregate makes a bigger difference than getting together and organizing.

Many of my participants, however, went further than merely affirming the power of the individual. Curtis (Age 35) argued that any ideology was the antithesis of his scientific worldview (and his particular approach to atheism): 
Okay. What is religion? It's an ideology, right? Beliefs not to be questioned. But, the real problem is ideology, right? Religion is just a subspecies of that. Science is anti-ideology. You know? It requires you to not accept things without proof. That's all atheism is at the end of the day. It's saying, 'I don't believe you.'

Curtis's emphasis on proof, consistent with his self-described skepticism, highlights the scientism that many critics associate with the movement, but it also illustrates my participants' attempts to distance themselves from a particular organization's collective identity or the imagined community as a whole (LeDrew 2015b; Pigliucci 2013).

Curtis was not alone in his commitments to individualism and scientism. For example, Connor (Age 27) described himself as a science geek, more interested in atheist activism based on critique, than communitybuilding:

The role of the atheist is that of a critic. Nothing more, nothing less. We're here to tell you that you're doing it all wrong. Others want to lump us in with this or that cause, but they can't. We're too diverse. We're too stubborn.

Several other participants also mentioned diversity, pointing out the value of intellectual differences. Their ambivalence towards more conventional social movement protests, with organizations leading the way under common collective identity frames, is reflective of broader trends towards fragmentation and individualization in contemporary society (Bennett and Segerberg 2013; Gauja 2015).

According to Haenfler et al. (2012: 14), activists in lifestyle movements politicize daily life while pursuing "morally coherent 'authentic' identities." Although other lifestyle movements have tended to focus on moral repertories as an essential component of identity-construction and activism (Kahl 2012), my participants drew from a range of intellectual (and ideological) sources to build their individual identities and do their atheism in the everyday:

My lifestyle is focused on bettering myself through exposure to critical thinking skills, science, history, you know? We're all just figuring this out as we go, but everyone I know in the community is deeply curious and committed to being better thinkers (Marco, Age 26)

Rather than just challenging theism and undermining religious privilege, my participants emphasized a skeptical, naturalistic worldview as the central component of their moral identity. This worldview is consistent with other scholarship that highlights secularists' broadly similar atti- 
tudes towards their activism based on the rejection of the supernatural, reliance on science, and a critical attitude towards religion (Cimino and Smith 2014).

Although atheism primarily refers to a skepticism towards God or gods, my participants associated their atheism with broader morally relevant principles informed by a scientific worldview. In other words, they did not just see themselves as atheists who happened to like science. Rather, they often espoused the virtues of an Enlightenment morality based on continuing triumph of reason, science, and secularism, perhaps explaining why they placed as much emphasis on critiquing paranormal and pseudoscientific claims (e.g., dowsing, ghosts, and cryptozoology, etc.) as they did religion. For example, during my research, one of the larger atheist organizations in Edmonton organized a protest of a television psychic and an opponent of both genetically modified food.

My participants' personal projects to improve the world through reason and science often placed them at odds with egalitarian-feminist perspectives:

I don't care if you're a feminist or not. It's not what you think but how you think. And I don't see much evidence-based reasoning among feminists. It's all knee-jerk reactions and emotional appeals (Bonnie, Age 39).

Bonnie's distinction between "correct thinking," and the perceived emotional content of social justice activism was a common theme in my interviews, particularly concerning feminism:

Being an atheist means that you're skeptical right? You're skeptical of religion, sure, but not just religion. As far as I'm concerned, nothing is off the table. I approach everything the same way, including political and economic perspectives (Terry, Age 43).

Terry associated her strained relationship with feminism with her skepticism, but not all of my participants shared her ambivalence towards feminism. Six of my participants explicitly identified as feminists, even while qualifying their identities to embrace their more libertarian viewpoints.

\section{Feminist with Qualified Support}

Although only a minority of my participants labeled themselves feminists, and rarely without qualification, most saw non-religiosity and atheism as gendered phenomena. Addressing the masculine tone of atheist activism and related cultures, e.g., geek culture (Inness 2016), many 
secularists observed a greater tendency among male atheists to be individualistic and instrumental, suggesting the stereotype that women operate from a collectivist, ensemble point of view. For example, Sasha (Age 31) argued that men might be more likely to engage in personal projects and hobbies that require significant time investment (like atheism):

I think there's definitely something about atheism that reminds me of teenage boys sitting in their basement learning magic tricks or something similarly obscure. Maybe one of the reasons we're not good 'joiners' is because of that. Most atheists I mean like to do things on their own [...] I feel like most women are more community-oriented.

The relationship between this gendered individualism and dissent (especially against Atheism Plus) was not always explicit in my participants' interviews, but many atheists were critical of the idea of an atheist movement with leaders or a standard set of principles beyond being pro-science.

Complementing the anti-ideology perspective, my participants emphasized the importance of critiquing all ideas based on logic and evidence, even if that meant alienating atheists who desired a more collectivist environment — one that placed a premium on social obligations and group harmony. For example, Tracy later expressed her concerns about SJWs trying to "hijack the movement," with its emphasis on a feminized social justice: "Their emotional appeals don't sway me. It's all about pulling on your heartstrings and for that reason, I don't see any of their feminist ideas as credible." Positing feminists as emotional, particularly angry, is a common strategy to delegitimize their criticisms, but my participants felt that they had a more nuanced view of feminism.

Sasha (Age 31) identified as a feminist, but she made a point to distinguish between the word feminism and the feminist movement: "I'm what Christina Hoff Sommers calls an equity feminist. It's all ultimately about choice for me." Equity feminism is a classically liberal or libertarian feminism (Sommers 1995). Similarly, Serena (Age 25) thought of herself as a feminist, but with qualifications:

I'm not that kind of feminist. Atheism Plus is full of radical feminists, and I'm not into that because [...] it's anti-science. They think sex is socially constructed. Whichever feminism embraces science, that's the kind I am.

Despite the fact that Serena associated Atheism Plus with science-denial and some of my other participants' contrasting of libertarianism and social justice, LeDrew (2015b) observes that Atheism Plus embraces the same scientism of the broader movement, given its apparent appreciation of and reliance on scientific methodologies. 
Sasha (Age 31) argued that while Atheism Plus supporters claimed to support science, they only supported the science that confirmed their point of view: "Watson and her supporters cherry-pick [science]. They avoid [any research] having to do with gender-just dismiss it out of hand." Although some of my participants' hostility towards Atheism Plus was ostensibly a reaction to perceived science-denial, even their emphasis on the epistemic authority of science emerged from a concern with ideology.

For many of my participants, their wariness about associating atheism with a particular political philosophy or belief system stemmed from their concerns about atheism turning into another religion. Of particular relevance to this article, several respondents argued that Atheism Plus was a "cult-like group," and that contemporary feminism was itself a religion. The feminism-as-religion argument is similar to Sommers' (1995) suggestion that "gender feminism" may be a religion given its emphasis on patriarchy.

Sommers' association with anti-feminist groups and the men's rights movement (MRA), may suggest that many people involved in secularist activism are similarly sympathetic to anti-feminism and other features suggestive of backlash (Jordan 2016). Assessing the gender politics of men's movements and men's rights groups and their potential association with atheist activism is beyond the scope of this article. Nevertheless, my data shows that some secularists have an apparent disinterest in, even hostility towards, feminism. It is not, however, clear if this hostility derives from feminism's challenges to sexism and male power or if something even more complex is at work. For example, Ryan (Age 31) expressed his antipathy towards "isms" in the community: "I'm strongly against 'isms' of any kind: nationalism, feminism [...] it doesn't really matter. If I had a religion, it would be against 'isms." When pressed, Ryan acknowledged that "vanilla" atheism was not entirely free from ideologies - or "isms" - and that those ideologies might even help activists achieve collective goals. But, he felt that to the extent that atheism had an ideology, it was consensual and grassroots-driven:

No one forces you to learn about critical thinking or cognitive biases or how to argue. It just sort of happens. Some people want to turn it into a system like they did with secular humanism, but that's not for me.

Given that many of my participants emphasized the importance of science and skepticism to their atheist lifestyles it was not surprising that they approached Atheism Plus with the same level of scrutiny that they did religion and pseudoscience. Moreover, all of my participants linked their atheism with a lifestyle based on scientific skepticism and critique, 
resulting in atheists distancing themselves from Atheism Plus's social justice ideology that placed issues of broader ethics and rights in the centre of atheist activism.

Underlying my participants' particular concerns with Atheism Plus, many were wary of organizational influence on the direction of atheist activism. In particular, they were concerned about the danger of ideology - one group purporting to hold the truth. Consequently, none of my participants felt that they needed atheist organizations or the broader movement to do their activism for them. Sean (Age 34) said that unlike the atheist movement, most social movements tend to ignore differences among activists and build walls between people. He also emphasized that doubt should be the default position within atheism: "It's a feature, not a bug." In keeping with this perspective, Haenfler et al., (2012: 8) argue that since lifestyle action is individualized and privatized instead of collective and public, "building strong personal connections between participants is not nearly as likely (nor possibly important) for [lifestyle movements]." Given Atheism Plus's broader community goals, the conflict between my participants and what they perceived to be an ideological threat to their lifestyles is consistent with the dynamics of some forms of secularist activism in Canada.

\section{Atheist Lifestyle And ACTivism}

During my research, the extent to which local atheist organizations supported atheists' personal projects became the standard by which my participants judged the effectiveness of their activism and the movement as a whole. For example, Raj (Age 33) argued that he only participated in atheist groups to the degree that they helped him evolve as a critical thinker:

I'm pretty selfish about my atheism. I want to learn about science, philosophy, and how to be better at reasoning. I don't come out for the 'community' stuff. I think a lot of atheists are introverts or on the spectrum, so I don't think I'm the only one who gets a little embarrassed when someone proposes making signs or stamping our feet outside city hall.

Raj additionally described Atheism Plus and the broader social justice influence on the movement as being contradictory to the atheist lifestyle:

Yeah, I guess it's a way of life. The things that makes us atheists is that we want to think for ourselves, right? And we suspect, you know, the herd mentality. At least that's what the impetus is for a lot of this. A lot of the impetus for turning into an atheist yourself is to say 'I'm myself.' 
Some of my participants additionally worried about the future impact of "political correctness" on the movement while others talked about "left-wing authoritarianism" and the "regressive left," just to name a few key phrases familiar to the online atheist community (Doolittle 2012; Xanthippa 2013).

In a Facebook discussion about Atheism Plus, continuing from an offline argument, Liam (Age 33) said, "My issue with Atheism Plus is that it adds both an element of "we believe in atheism/skepticism, plus this dogma that shall not be questioned." The discussion that followed highlighted the reticence of some community members to embrace a broader mandate for atheist activism and their general distrust of left-wing progressivism, particularly in the form of political correctness.

Although not explicit in interviews, my participants often associated the perceived influence on political correctness with a feminine atheism, e.g., emphasis on accommodationist politics, community-building, and stronger roles for atheist organizations. For example, Trevor (Age 28), associated the brief popularity of Atheism Plus with attempts to make atheism more like a secular church:

I see a lot of emphasis being placed on community these days: potlucks, child-safe gatherings, atheist churches, charity work, board-game nights, etc. I'm not saying I don't like those things, but they seem to appeal most to women and families. I preferred it when being part of an atheist group meant criticizing religion and learning cool stuff. Now it's more like a church.

Although Trevor was concerned about what he saw as the "slow advance of political correctness," he was mostly concerned about collectivism in atheist politics, which is consistent with the libertarianism of the movement.

Despite my participants' concerns about political correctness and their emphasis on individualized and personalized action, all of my interviewees associated with one or more atheist organizations. Some wanted the organizations to do more, e.g., organize protests, challenge the provincial government, etc., but they nevertheless preferred self-direction in their activism with the understanding that others were doing the same in a supportive environment (Haenfler et al. 2012). Consequently, the majority of my participants did not engage in organized activism as an expression of their atheism.

Participants in lifestyle movements often prefer direct action and prefiguration rather than mobilization through formal political organizations. In other words, they focus on daily choices. For example, Tricia 
(Age 30) described her atheism as a process rather than just a consequence of leaving religion:

I think a lot of people think of activism as standing out there with a sign, but it's ultimately about personal growth. It's about stripping away all the falsehoods and cobbling together something out of the remaining pieces. I don't think it ever stops for any atheist regardless of how accepted we might be now.

Tricia's personalization of her activism as a process does not preclude activism or solidarity, but my findings show that atheist collective identity promotes individual action over organizational forms of protest. Some of my participants went so far as contest the term "atheist," following Harris (2007) who argued the term should not exist. For example, Lisa (Age 32) said that no one goes around "calling themselves aleprechaunists [lack of belief in leprechauns], so why call ourselves atheists?" Given my participants level of skepticism concerning even the term atheist, one of my most common follow-up questions was why they identified with an organization or movement at all. Some responded that there were few alternatives for expressing their atheism free of perceived or actual stigma. As with other lifestyle movements, however, most of my participants' acknowledged their desire to feel connected to a broader collective identity, but not at the expense of individual and private action.

\section{Discussion ANd Conclusion}

The purpose of this study has been to increase our understanding of why some atheist activists are resistant to the social progress of factions like Atheism Plus. I also aimed to show that some atheists engage in a methodological (and gendered) lifestyle politics that is hostile towards ideology. To explain atheist activism as a lifestyle practice, I offered an in-depth case-study of Edmonton atheist activists and their responses to the emergence of Atheism Plus as a primarily online phenomenon, but with significant implications for the direction of atheist activism.

I found that most atheist activists in Edmonton became a member of an atheist organization to guide and shape their individualistic approaches to living an atheist lifestyle based on Enlightenment values. To the extent that my participants sought social change, they emphasized the importance of living a reasoned life imbued by science and skepticism. These findings are similar to other studies of atheist activists (LeDrew 2015; Smith 2013). In this study, I build on this previous work, but also add a new dimension by employing lifestyle movement theory to explain 
my participants' engagement with lifestyle politics. This contribution highlights the importance of individualized and private activism to atheists who are suspicious of ideology, attachment, and belief (Lorenzen 2012; Portwood-Stacer 2012).

Atheism Plus's failure to frame their interests successfully to the mainstream of the movement, that is, scientific atheists who value individualism and skepticism, emerged from an inherent conflict between feminist identity politics emphasizing the institutional underpinnings of power, e.g., patriarchy, and my participants' emphasis on a community of individuals with different sociopolitical inclinations and goals. The conflict is historical, between "liberal individualism and a humanistic atheism rooted in social justice" (LeDrew 2015a: 65). Building on this argument, my data shows participants did not so much construct their identity based on negation or opposition to religion, but as critical thinkers engaged in a personal project of intellectual development and skepticism. To the criticism that atheist activists are ineffective due to their consistent focus on individualism and the movement's propensity to fragment (LeDrew 2015b), my research shows that many secularists are content to promote lifestyle change because it allows them to indulge in a shared ethos while maintaining their personal authenticity. Although this emphasis on personal identity may limit collective mobilization, for my participants it encouraged multiple perspectives free of ideology and dogma.

\section{REFERENCES}

Amarasingam, Amarnath. and Brewster, Melanie Elyse., 2016. The rise and fall of the new atheism: Identity politics and tensions within us nonbelievers. In Annual Review of the Sociology of Religion: Sociology of Atheism, edited by R. Cipriani and F. Garelli, 118. Leiden and Boston: Brill.

Algozzine, Bob. and Hancock, Dawson., 2016. Doing Case Study Research: A Practical Guide for Beginning Researchers. New York and London: Teachers College Press.

Anne, Libby. 2012. What the history of feminism has to teach Atheism. Access date: February 12, 2016. http: //www.patheos.com/blogs/lovejoyfeminism/2012/08/what-the-history-of-feminism-has-to-teach-atheism.html

Beaman, Lori G. and Tomlins, Steven. eds., 2014. Atheist Identities-Spaces and Social Contexts (Vol. 2). Springer.

Bennett, W. Lance, 2012. The personalization of politics: Political identity, social media, and changing patterns of participation. The ANNALS of the American Academy of Political and Social Science, 644(1), pp.20-39. 
Bennett, W. Lance. and Segerberg, Alexandra., 2013. The Logic of Connective Action: Digital Media and the Personalization of Contentious Politics. Cambridge: University Press.

Cherry, Elizabeth., 2015. I was a Teenage Wegan: Motivation and Maintenance of Lifestyle Movements. Sociological Inquiry, 85(1), pp.55-74.

Cimino, Richard, and Christopher Smith. 2014. Atheist Awakening: Secular Activism and Community in America. New York: Oxford University Press.

Cipriani, Roberto. and Garelli, Franco. eds., 2016. Annual Review of the Sociology of Religion: Sociology of Atheism. Leiden and Boston: Brill.

Dobernig, Karin. and Stagl, Sigrid., 2015. Growing a Lifestyle movement? Exploring Identity-work and Lifestyle Politics in Urban Food Cultivation. International Journal of Consumer Studies, 39(5), pp.452-458.

Doolittle, Mike. 2012. The A-Unicornist: Atheism Plus? Access date: February 15, 2016. http: //www.theaunicornist.com/2012/08/atheism-plus.html.

Flyvbjerg, Brent., 2006. Five Misunderstandings about Case-study Research. Qualitative inquiry, 12(2), pp.219-245.

Gauja, Anika., 2015. The Individualisation of Party Politics: The Impact of Changing Internal Decision-making Processes on Policy Development and Citizen Engagement. The British Journal of Politics and International Relations, 17(1), pp.89-105.

Haenfler, Ross. 2004. Collective Identity in the Straight Edge Movement. The Sociological Quarterly, 45(4), 785-805.

Haenfler, Ross, Brett Johnson, and Ellis Jones. 2012. Lifestyle Movements: Exploring the Intersection of Lifestyle and Social movements. Social Movement Studies 11, no. 1: 1-20.

Harris, Sam. 2007. The Problem with Atheism. Access date: February 15, 2016. http: //www.samharris.org/blog/item/the-problem-with-atheism.

Inness, Sherrie. ed., 2016. Geek chic: Smart women in Popular Culture. Springer.

Jordan, Ana., 2016. Conceptualizing Backlash: (UK) Men's Rights Groups, Anti-Feminism, and Postfeminism. Canadian Journal of Women and the Law, 28(1), pp.18-44.

Kahl, Kristina., 2012. My God Wants Me to Live Simply: The Constructed Selfhood of Faith Based Simple Livers. Symbolic Interaction, 35(3), pp.249266.

Kettell, Steven., 2013. Faithless: The politics of New Atheism. Secularism and nonreligion, 2.

Kettell, Steven. 2014. Divided We Stand: The Politics of the Atheist Movement in the United States. Journal of Contemporary Religion 29, no. 3: 377391. 
Laflamme, Sarah Wilkins. 2015. How Unreligious are the Religious Nones? Religious Dynamics of the Unaffiliated in Canada. Canadian Journal of Sociology 40, no. 4: 477-500.

Langston, Joseph, Joseph Hammer, and Ryan T. Cragun. 2015. Atheism Looking In: On the Goals and Strategies of Organized Nonbelief. Science, Religion and Culture 2, no. 3: 70-85.

Larsson, Christel L., Rönnlund, Ulla., Johansson, Gunnar. and Dahlgren, Lars., 2003. Veganism as Status Passage: The Process of Becoming a Vegan Among Youths in Sweden. Appetite, 41(1), pp.61-67.

Laughlin, Jack C., 2017. Varieties of an Atheist Public in a Digital Age: The Politics of Recognition and the Recognition of Politics. The Journal of Religion, Media and Digital Culture, 5(2), pp.315-338.

LeDrew, Stephen. 2013. Discovering Atheism: Heterogeneity in Trajectories to Atheist Identity and Activism. Sociology of Religion, 74(4), 431-453.

LeDrew, Stephen. 2015a. Atheism versus humanism: Ideological tensions and identity dynamics. In Atheist Identities-Spaces and Social Contexts, edited by L.G. Beaman and S. Tomlins, 53-68. Springer International Publishing.

LeDrew, Stephen. 2015b. The Evolution of Atheism: The Politics of a Modern Movement. Oxford University Press.

Lorenzen, Janet A., 2012, March. Going Green: The Process of Lifestyle Change. In Sociological Forum (Vol. 27, No. 1, pp. 94-116). Blackwell Publishing Ltd.

Marx, Gary T. and McAdam, Doug., 1994. Collective behavior and social movements: Process and structure. Pearson College Div.

McCreight, Jen. 2011. Richard Dawkins, your privilege is showing. Access date: February 2, 2012. http: //www.blaghag.com/2011/07/richard-dawkinsyour-privilege-is.html

Micheletti, Michele. and McFarland, Andrew S., 2015. Creative participation: Responsibility-taking in the Political World. New York: Routledge.

Miller, Ashley. 2013. The Non-religious Patriarchy: Why Losing Religion has not Meant Losing White Male Dominance. CrossCurrents, 63(2), 211226.

Myers, Paul Z. 2011. Why Are You an Atheist? Access date: February 15, 2016. http: //scienceblogs.com/pharyngula/2011/02/01/why-are-you-an-atheist

Nixon, Alan. 2014. New Atheism as a Case of Competitive Postsecular Worldviews (Ph.D). The University of Western Sydney.

Pigliucci, Massimo., 2013. New Atheism and the Scientistic Turn in the Atheism Movement. Midwest Studies in Philosophy, 37(1), pp.142-153. 
Portwood-Stacer, Laura., 2012. Anti-consumption as Tactical Resistance: Anarchists, Subculture, and Activist Strategy. Journal of Consumer Culture, 12(1), pp.87-105.

Schnabel, Landon. 2015. Religion and Gender Equality Worldwide: A Countrylevel Analysis. Social Indicators Research, 1-15.

Smith, Christopher, and Richard Cimino. 2012. Atheisms Unbound: The Role of the New Media in the Formation of a Secularist Identity. Secularism and Nonreligion 1.

Smith, Jesse. 2013. Creating a Godless Community: The Collective Identity Work of Contemporary American Atheists. Journal for the Scientific Study of Religion, 52(1), 80-99.

Smurthwaite, Kate. 2016. Atheism is an Old Boys' Club. More Women Should Admit to Being Godless. Access date: January 29, 2016. http: //www. telegraph.co.uk/women/life/atheism-is-an-old-boys-club-more-womenshould-admit-to-being-god/

Snow, David A. and Trom, Danny., 2002. The Case Study and the Study of Social Novements (Vol. 16, pp. 146-172). Minneapolis: University of Minnesota Press.

Sommers, Christina H., 1995. Who Stole Feminism?: How Women have Betrayed Women. Simon and Schuster.

Statistics Canada. 2013. The Daily - 2011 National Household Survey: Immigration, Place of Birth, Citizenship, Ethnic Origin, Visible Minorities, Language and Religion. Statistics Canada, May 8. Access date: April 7, 2017. http: //www.statcan.gc.ca/daily-quotidien/130508/dq130508b-eng. htm.

Tomlins, Steven. 2015. A Common Godlessness: A Snapshot of a Canadian University Atheist Club, Why Its Members Joined, and What That Community Means to Them. In Atheist Identities-Spaces and Social Contexts, edited by L.G. Beaman and S. Tomlins, 117-136. Springer International Publishing.

Tomlins, Steven., 2016. Navigating Atheist Identities: An Analysis of Nonreligious Perceptions and Experiences in the Religiously Diverse Canadian City of Ottawa (Doctoral dissertation, Université d'Ottawa/University of Ottawa).

Voas, David. 2015. The Normalization of Non-religion: A Reply to James Lewis. Journal of Contemporary Religion 30, no. 3: 505-508.

Watson, Rebecca. 2011. About Mythbusters, Robot Eyes, Feminism, and Jokes. YouTube. Access date: February 15, 2016. http: //www.youtube.com/ watch? $\mathrm{v}=\mathrm{uKHwduG1Frk}$.

Willis, Margaret M. and Schor, Juliet B., 2012. Does Changing a Light Bulb Lead to Changing the World? Political Action and the Conscious Consumer. The ANNALS of the American Academy of Political and Social Science, 644(1), pp.160-190. 
Xanthippa, 2013. Thunderf00t: Why Feminism Is Poisoning Atheism (Part 4). Access date: February 15, 2016. http: //blog.xanthippas.com/2013/08/16/ thunderf00t-why-feminism-is-poisoning-atheism-part-4/.

Yates, Luke., 2015. Everyday Politics, Social Practices and Movement Networks: Daily Life in Barcelona's Social Centres. The British Journal of Sociology, 66(2), pp.236-258.

Yin, Robert K., 2011. Applications of Case Study Research. Sage.

Zuckerman, Phil., Galen, Luke W. and Pasquale, Frank L., 2016. The Nonreligious: Understanding Secular People and Societies. Oxford University Press.

Jonathan Simmons is a $\mathrm{PhD}$ candidate in Sociology at the University of Alberta. His SSHRC-funded dissertation examines the identities and lifestyles of atheist activists in Alberta, Canada.

E-Mail: jsimmon@ualberta.ca 